\title{
Contaminated sites in China: Countermeasures of provincial governments
}

\author{
Xiaonuo Li ${ }^{\text {a, b }}$, Wentao Jiao ${ }^{\text {a }}$, Rongbo Xiao ${ }^{c}$, Weiping Chen ${ }^{\mathrm{a}, ~ *}$, Wen Liu ${ }^{\mathrm{d}}$ \\ a State Key Laboratory of Urban and Regional Ecology, Research Center for Eco-Environmental Sciences, Chinese Academy of Sciences, No. 18, Shuangqing \\ Road, Beijing 100085, PR China \\ ${ }^{\mathrm{b}}$ Graduate University of Chinese Academy of Sciences, No. 19, Yuquan Road, Beijing 100049, PR China \\ c Guangdong Provincial Academy of Environmental Science, No. 335, Dongfeng Road, Guangdong 510045, PR China \\ ${ }^{\mathrm{d}}$ Key Laboratory of Ecohydrology of Inland River Basin, Cold and Arid Regions Environmental and Engineering Research Institute, Chinese Academy of \\ Sciences, No. 320, Donggangxilu, Lanzhou 730000, PR China
}

\section{A R T I C L E I N F O}

\section{Article history:}

Received 20 June 2016

Received in revised form

18 January 2017

Accepted 19 January 2017

Available online 20 January 2017

\section{Keywords:}

Contaminated sites

Decision making

Site sustainability management

Environmental policy analysis

\begin{abstract}
A B S T R A C T
Contaminated sites have caused worldwide attention and been dealt with through a variety of policies and practices both nationally and regionally. Unlike the US, Canada, Japan, and Europe, which have accumulated rich experiences in contaminated site management, China, facing serious contaminated site issues, still lacks effective strategies on issues such as remediation standards, funding resources, accountability, and stakeholders coordination. This paper collected policies for contaminated site management from 31 regions in China. A comprehensive analysis was conducted of current policies, including policy framework, number of policies and instruments, policy types, and spatial and temporal variation. We find that most regions in China, such as Beijing and Chongqing, have taken positive measures to manage contaminated sites, and that there are similarities as well as differences in policy responses and mechanisms in different regions. A multi-level objective system, combined with diverse instruments, cooperation between different stakeholders, and a multi-sectoral joint supervision mechanism emphasized by all 31 regions, are extremely important to promote sustainable site management. Specialized policies, site-specific standards, information disclosure, public participation, remediation priority and groundwater protection are urgently needed to strengthen the local framework of contaminated site management and to promote remediation projects.
\end{abstract}

() 2017 Elsevier Ltd. All rights reserved.

\section{Introduction}

Contaminated land, defined as land containing substances in or under it that are actually or potentially hazardous to health or the environment, has given rise to great concern worldwide because of its significant adverse effects on human health and the environment (Bergius and Öberg, 2007; Greenberg and Lewis, 2000; van Straalen, 2002). To effectively address contaminated sites, strategies and successful experiences through a variety of soil protection policies have been implemented in the US, Canada, Japan, and Europe during the last 20-30 years (Bouma and Droogers, 2007; Gong, 2012; Ma, 2009; Prokop, 2005; Tarazona et al., 2005).

\footnotetext{
* Corresponding author.

E-mail addresses: lixiaonuo1988@163.com (X. Li),wtjiao@rcees.ac.cn (W. Jiao), ecoxiaorb@163.com (R. Xiao),wpchen@rcees.ac.cn (W. Chen), liuwen08@lzu.edu. cn (W. Liu).
}

Among them:

- The Comprehensive Environmental Response Compensation and Liabilities Act (CERCLA, 1980) that referred to Superfund enacted by Congress was considered the most representative law for contaminated site management especially specific provisions for remediation fund and liability (Gu et al., 2007). This law defined liability of persons responsible for site remediation, created a tax on the chemical and petroleum industries, established a trust fund for cleanup when no responsible party could be identified and provided broad Federal authority to respond directly to releases of hazardous substances (USEPA, 1980). The National Priorities List (NPL), the list of national priorities among the known releases or threatened releases of hazardous pollutants in the United States, and Hazard Ranking System (HRS), a tool to determine if a site is a candidate for inclusion on the NPL by numerically ranking of site risks, are another useful 
tools in Superfund program that help listing a total of 1328 uncontrolled hazardous waste sites on NPL by 2016, among which, 391 Sites have been cleaned up and deleted from the lists (USEPA, 2016).

- The Netherlands is among the earliest countries in the world to develop a policy for contaminated land management (Swartjes et al., 2012). Its success appears to manage contaminated sites from a risk assessment perspective that are facilitated by (1) policy aim of 'fitness-for-use' approach evolved from originally multifunctional soil reuse after remediation; (2) the concept of "sustainable soil management" in Soil Quality Decree (2008) to ordinate a balance between environment, society and economy; (3) a formalized three-step, tiered approach to determine the urgency of remediation; (4) the risk-based Soil and Groundwater Quality Standards.

- Britain, as one of countries facing a legacy of contaminated land left by rapid economic growth, the contaminated site management is regulated by different legislative regimes including Part 2A of Environmental Protection Act 1990, Town and Country Planning Act 1990, Water Resource Act 1991 and Planning Policy Guidance 23 (Luo et al., 2009; DEFRA, 2012). In addition to "soil guideline values" approach and "the risk-based decision-making" approach, sustainable management that bases on "sourcepathway-receptor" linkages and focuses on site rehabilitation could be useful assets for China. Respond to the policy regimes, projects including HOMBRE (Holistic Management of Brownfield Regeneration), SuRF-UK (Sustainable Remediation Forum UK) and GREENLAND (Gentle Remediation of Trace Element Contaminated Land) are funded and supported by effective computer-based tools including BOM (Brownfield Opportunity Matrix) and CSM (Conceptual Site Model) to manage complicated decision-making processes and encourage the sustainable land regeneration (Bardos and Menger, 2013; CL:AIRE, 2011; Beumer et al., 2014).

In China, contaminated sites have become a new and serious environmental problem, especially those emerging from the process of relocating old and polluting industries from urban centers due to upgrade of industrial structure and adjustment of urban layout (Liao et al., 2011). It has been estimated that there are more than 200,000 contaminated sites in China, 320 of which were identified as serious contaminated sites covering 5.48 million hectares (Everbright Securities, 2013). In the context of this study, contaminated sites are specifically noted for industrial spaces left by closing, suspending, and relocating industrial companies. To deal with contaminated site issues and achieve soil protection objectives, an effective policy system must be developed at national, regional, and local levels. In recent years, the central government has introduced numerous policies such as Recommendations on Strengthening Soil Contamination Prevention and Remediation (2008) and Technical Guidelines for Site Soil Remediation (2014). In particular, Active Plan on Soil Contamination Prevention (2016) was released recently, aiming to improve soil environment quality gradually. With these policies, a central legislative system of contaminated site management has developed, although several aspects, including soil specific act, soil quality standards and remediation goals, liability and funding, risk-based management, stakeholder participation and information disclosure, remediation priorities, and industrial access requirements, still need to be improved. In contrast, regional actions are quite slow in contaminated site management, except for a few provinces and municipalities such as Beijing, Chongqing, Zhejiang, and Jiangsu. It needs to be noted that policy includes four tiers: namely act, regulation, ordinance, and standard. An "act" is a formative document with the highest legal status in the land. It was submitted to, deliberated upon, and passed by the National People's Congress or Standing Committee of the National People's Congress. A "regulation" is an authoritative rule or decree issued by the State Council, Local People's Congress and its Standing Committee, the legislative organs of the self-governing national autonomous regions, and the People's Congress of special economic zone provided it did not exceed the mandate authorized in the "act"; it would be applicable only within the respective jurisdictions of the issuers. An "ordinance" is a rule or decree prescribed by superior or competent authority and issued by the executive branch of government through an agency such as the Ministry of Environmental Protection provided that it did not exceed the mandate authorized in the "act"; it would be applicable only within the respective jurisdictions of the issuers. A "standard" is the scientifically-based critical threshold of pollution established by appointed authorities for the purposes of implementing the rules and decrees, and often is independent and recognized across the legal hierarchies.

There have been many studies on contaminated site management in different regions focusing on regional comparison of risk assessment, clean-up criteria, stakeholder engagement, liability, and funding issues (D'Aprile et al., 2007; Bluffstone, 2007; Cundy et al., 2013; Johansson et al., 2011; Provoost et al., 2006; Rodrigues et al., 2009; Sousa, 2001; Swartjes et al., 2012). Some national studies summarized and compared Chinese policies with the US Super Fund Liability System and Japan's soil pollution control legal system (Jin, 2012; Luo et al., 2009; Li, 2011, 2012; Liu et al., 2013; Wang, 2012; Zhao et al., 2006). However, comprehensive policy study on contaminated site management in various regions in China is limited. Local government is the main responder to contaminated sites. Their actions, responses, policies, and mechanism are critical to contaminated site management in China.

In this research, we compared the provincial differences in policies for contaminated site management from 22 provinces, 5 autonomous regions, and 4 municipalities (excluding Chinese Taipei; Macao, China; Hong Kong, China) in China. The policy system is analyzed from the perspectives of policy framework (Section 2), policy instruments (Section 3), policy types (Section 4), and spatial and temporal variation (Section 5) to present the regional differences in issues such as liability, funding, priority, standards, and supervision. Finally, six recommendations at provincial and municipal level (Section 6) were proposed to accelerate contaminated site sustainable management in China. The systematic policy analysis and main findings aim to provide valuable references for future policymaking, possible remediation projects, and ongoing site management.

\section{Policy framework for contaminated site management in various regions}

Analysis of the policy framework for contaminated site management is carried out based on the specific policy components of policy objectives, policy instruments, and policy stakeholders (Fig. 1), which reflect the process by which policies function. To further explain each component orderly, the description of the hierarchical framework is firstly extended logically from top to down, correspondingly, from policy objective to stakeholders, and then employed to evaluate the different performance at provincial level combing the policy status in the context of specific province.

\subsection{Policy objectives}

Objective is the fundamental component of policy framework, which can be divided into ultimate objective, phased objective, and action objective (Song, 2008). As illustrated by Fig. 1, the ultimate objective of contaminated site management was principally set as 


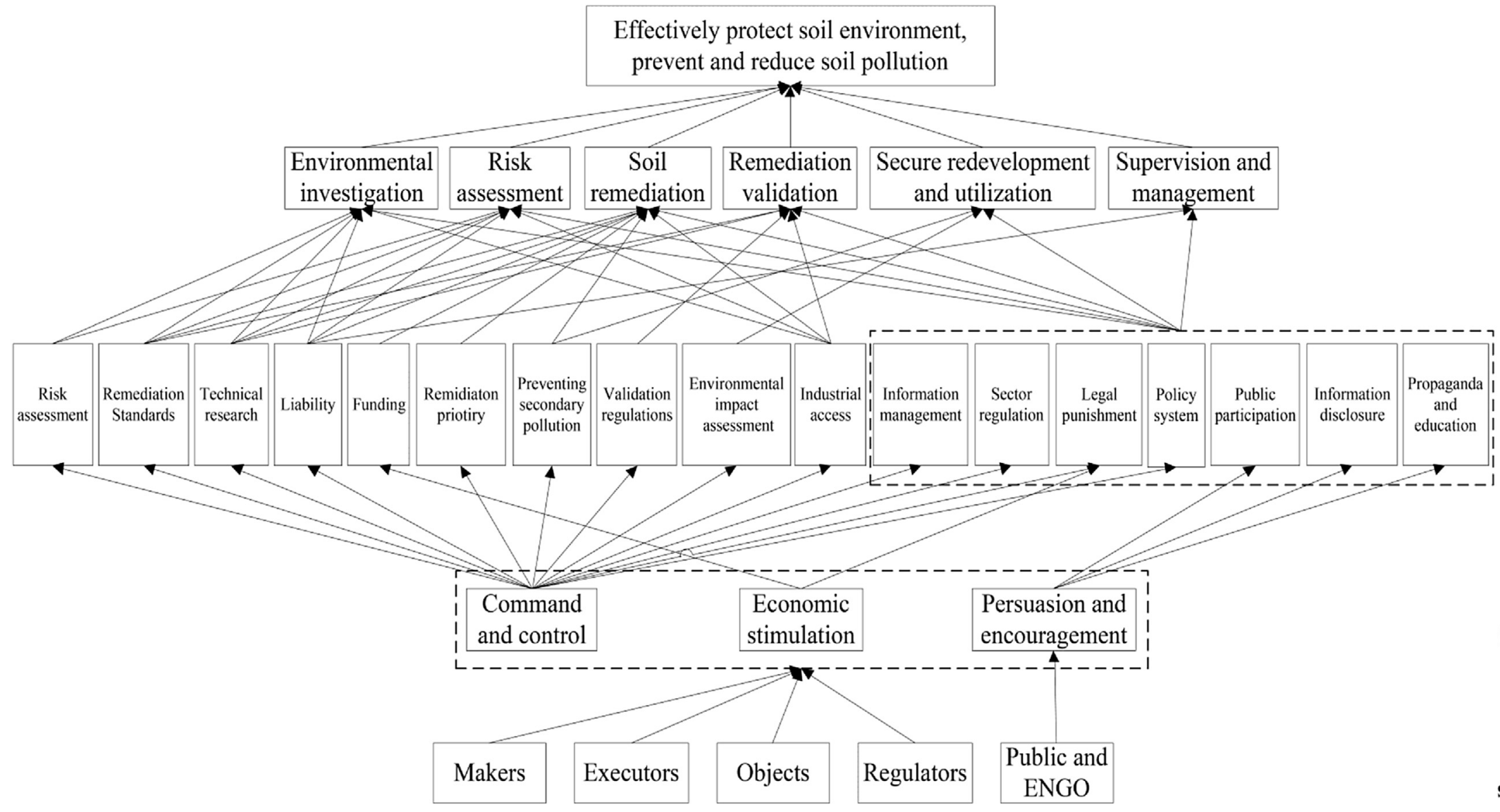

Ultimate objective

Phased

objective

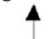

Policy

Action

objective

instruments

$\wedge$

Policy

stakeholders

Fig. 1. Elements analysis of contaminated site management policies in 31 regions of China. 
“effectively protect soil environment, prevent and reduce soil pollution, initially control environmental and human health risks of contaminated land redevelopment and comprehensively enhance ability of soil environmental supervision." The ultimate objective is a long-term goal that is difficult to achieve and control but that formulates the fundamental standards of conduct. It is taken as guidance for all policy instruments and stakeholders. Under the ultimate objective, six phased objectives are developed: environmental investigation, risk assessment, soil remediation, validation, secure redevelopment, and supervision and management. It is based on contaminated site management procedures, and is highly controllable government decision-making. To realize phased objectives easily, action objectives are set up along with each phased objective. A total of 17 action objectives are included in the framework, such as identifying responsibility, preventing secondary pollution, regulating industrial access requirements, and improving the policy system. Among them, 7 action objectives are involved in each phased objective: improving information management, strengthening sector regulation, aggravating legal punishment, improving policy system, encouraging public participation, intensifying outreach and education, and promoting information disclosure. The phased objective of contaminated soil remediation is the most complicated involving 14 action objectives, while the phased objective of supervision and management is relatively simple involving 8 action objectives.

\subsection{Policy instruments}

Policy objectives have to be realized with the support of feasible instruments (Chang et al., 2013). Policy instruments usually refer to government measures to prevent, control, or eliminate negative environmental impacts caused by human activities (Song, 2008). Based on the Chinese policy regime, it can be divided into three categories: command and control, economic stimulation, and persuasion and encouragement (Song, 2008). Policy instruments applied to contaminated site management in China combine the aforementioned three types and place command and control first, with economic stimulation second and persuasion and encouragement as a supplement (Fig. 1). With the emergence of new environmental problems and pollution characteristics, the types of policy instruments are increasingly diversified.

The command and control instrument acts on objects directly by means of standards, regulations, or orders to control pollutant emissions. Thus it is the most common method of solving environmental problems globally for explicit expectations and high efficiency on object behavior and policy outcomes (Song, 2008). In the framework, 13 types of command and control instruments, such as standards, bans, environmental impact assessment, control pollution by a deadline, supervision and management, risk assessment, and liability, are selected to manage site soil pollution (Fig. 1). Standard is the basis of command and control instruments, but Environmental Quality Standard for Soils (1995) has been unsuitable to conduct risk assessment and soil remediation because of the presence of only a few types of soil pollutants (eight kinds of heavy metal and two kinds of organic compound) and a narrow scope of application (agricultural- and forest lands-oriented) (Zhu, 2011). In this situation, some cities, such as Beijing and Chongqing, and Zhejiang province have attempted to develop screening values, action values, remediation target values, and remediation validation values on land reuse types and human health risks (Table 1). For the first time, Guidelines for Risk Assessment of Contaminated Site in Zhejiang province (unreleased) takes groundwater protection into account to define soil screening values and remediation goals considering the inter diffusion of pollutants between soil and groundwater that is of great importance to thoroughly eliminate health risks and protect the soil environment. Hunan and Henan province formulate the range and standards of sites that may be contaminated and need to be assessed should be developed by the provincial department of environmental protection as well as the competent department of land and resources, department of agriculture, or department of housing and urban-rural development.

The economic stimulation instrument affects policy objects indirectly from a cost-benefit perspective. Therefore, policy outcomes can be influenced by other factors including market completeness, which may lead to worse execution compared with command and control instrument. Funding and fines are two main economic stimulation instruments to execute policies. The Recent Plan of Soil Environment Protection and Comprehensive Cleanup in Jiangsu province (2013) has recommended diversified investors including government, companies, and society, and established a sustainable development reserve, credit and taxation, and a compensation mechanism for reducing the use of outdated capacity and an environmental pollution-related liabilities insurance system to perfect a financing system for contaminated site management.

Prevention and control planning for heavy metal pollution of Fujian, Hubei, Liaoning, Inner Mongolia, and Shandong province introduced various environmental economic policies and financing channels such as financial incentives and subsidy to prevent and decontaminate heavy metal pollution, which can provide references for contaminated site remediation. Penalty provisions are the inherent constituent of policies to ensure the achievement of policy objectives (Chang et al., 2013). Regulations of Environmental Protection of Chongqing Municipality (2007) and regulations of Henan, Hunan, Shaanxi, Sichuan, and Zhejiang provinces on pollution prevention and treatment caused by soil waste developed clear penalty standards for violations that fail to remediate contaminated soil and for violators who do not make the corrections within the time limit after redeveloping remediated land that does not meet the requirements of environmental protection. Shaanxi imposes the severest penalty, with a fine of double to three times the remediation expenses, while fines in other provinces range from 5000 to 300,000 RMB.

The persuasion and encouragement instrument affects policy objects by outreach, education, or forming social pressure, and the characteristic of non-mandatory regulation will take a long time to be effective (Song, 2008). Outreach and education, information disclosure, and public participation are three main persuasion and encouragement instruments in contaminated site management policies. However, they are inadequate in current policies and specific definitions of them are often lacking. The principles to "establish information release system," "disseminate scientific knowledge by outreach and education," and "promote public participation" are built in most provincial policies but lacking practicality and maneuverability for no specification defined to facilitate their application in contaminated site management on who execute these provisions, how to implement, an what kind of information should be disclosed and educated. Here is the case itemized as following:

a) Information disclosure: Publicized soil pollution information is seen as an effective enforcement mechanism worldwide that will promote conventional policy implementation as well as triggering new coping strategies and management mechanisms. The call for public access to soil pollution information collected by polluters and state agencies got an international impetus to promote policymaking. By 2006, almost 70 countries had passed access-to-information legislation (Banisar, 2006). In China, the Notice of Strengthening Environmental Management during the Relocation of Industry in Wuhan (2012) regulated that 
Table 1

Theoretical basis for standards in regional policies.

\begin{tabular}{|c|c|c|c|c|c|}
\hline Regions & Policies & Soil screening values & $\begin{array}{l}\text { Action } \\
\text { values }\end{array}$ & Remediation target values & Validation standards \\
\hline \multirow[t]{3}{*}{ Beijing } & Environmental Site Assessment Guideline & USEPA Soil Screening Levels & $\begin{array}{l}\text { Based on } \\
\text { health risk }\end{array}$ & - & - \\
\hline & $\begin{array}{l}\text { Technical Guideline for Contaminated } \\
\text { Sites Remediation Validation }\end{array}$ & - & - & - & $\begin{array}{l}\text { Based on remediation } \\
\text { target value }\end{array}$ \\
\hline & $\begin{array}{l}\text { Screening Levels for Soil Environmental } \\
\text { Risk Assessment of Sites }\end{array}$ & Based on land reuse types & - & Based on health risk & - \\
\hline Chongqing & $\begin{array}{l}\text { Technical guideline for Environmental } \\
\text { Risk Assessment of Sites }\end{array}$ & - & $\begin{array}{l}\text { Based on } \\
\text { health risk }\end{array}$ & $\begin{array}{l}\text { A level in Standard of Soil Quality } \\
\text { Assessment for Exhibition Sites }\end{array}$ & - \\
\hline Zhejiang & $\begin{array}{l}\text { Guidelines for Risk Assessment of } \\
\text { Contaminated Site }\end{array}$ & $\begin{array}{l}\text { Based on land reuse types and } \\
\text { groundwater protection }\end{array}$ & - & $\begin{array}{l}\text { Based on health risk, groundwater } \\
\text { protection }\end{array}$ & - \\
\hline
\end{tabular}

contaminated site occupiers should release completion notice immediately after remediating contaminated sites. Administrative Methods for Cleanup and Remediation of Contaminated Lands in Shenyang (2007, trial edition), the 12th Five-Year Planning for Environmental Protection of Gansu Province (2011), and prevention and control planning for heavy metal pollution of Shandong and other provinces proposed that competent departments of environmental protection should regularly publish the status of soil remediation and soil polluted by heavy metal to guarantee the public right to know. By far, relevant information is unavailable on governmental information disclosure websites in the regions mentioned above.

b) Outreach and education: There are no specific provisions on outreach and education approaches for contaminated site management, and both the weak enforcement of departments and negative attitudes of the public are obstacles for the implementation of policy instruments and improvement of public awareness. Materials, training, seminars, and media are available for disseminating hazards, prevention, control, and treatment of heavy metal pollution in prevention and control planning for heavy metal pollution of Shandong and Liaoning province, to increase the public sense of self-protection and ability to respond in coping with an emergency. Referring to the multiple approaches listed above, outreach and education on characteristics of soil pollution (pollutants, pollution level and reason, hazards), a remediation plan (environmental impact, schedule, remediation time, and technology), and land reuse can also be launched as soon as possible to guide the public to understand hazards of contaminated sites and improve public perceptions of soil protection. Preferred approaches for outreach and education can be determined by collection data from residents exposed to contaminated sites by questionnaires and interviews.

c) Public participation: Administrative Methods for Cleanup and Remediation of Contaminated Lands in Shenyang (2007, trial edition) encouraged any groups or individual to report and accuse violators who caused site pollution, and consult with experts and the general public by holding hearings especially at the sites that may significantly affect the environment and jeopardize the public interest. However, insufficient and undisclosed information about the contaminated sites make public participation unrealistic and ineffective in the current situation.

\subsection{Policy stakeholders}

Effective stakeholder engagement and the balance of opposing interests of various stakeholders are pivotal in achieving sustainable project management, and stakeholder analysis is the most efficient way to identify all relevant stakeholders. The "rainbow diagram" (Fig. 2) classifies stakeholders according to the degree to which they can affect or be effected by a problem or a management action (Chevalier and Buckles, 2008). Regulators involved in policy making, issue, execution and oversee, e.g. the people's governments at various levels as well as departments of environmental protection, have profound influence on management actions but little interest. Polluters and redevelopers have high interest in, but low influence on, management actions. The investigation, remediation, and validation enterprises have little control of policymaking but their work is very much effected and strictly constrained by policy measures. In addition, the interests and demands of the public and environmental nongovernment organizations may affect and in turn be effected by policy decisions.

The people's governments at various levels bear the overall responsibility for soil environmental protection and comprehensive management of the administrative areas. The Environmental Protection Department (Bureau) (EPD) is responsible for uniform supervision and management, examination and approval of feasible plans for contaminated site investigation and remediation, establishment of contaminated site lists, popularity of advanced technology and experience, outreach of soil protection knowledge, information disclosure of contaminated site investigation, risk assessment, remediation and validation, providing for public participation, and claiming accountability of violators, among other responsibilities.

The Development and Reform Commission (DRC) and Economic and Information Technology Commission (EITC) are responsible for eliminating backward production capacity and upgrading the industrial structure to prevent soil pollution. The Department (Bureau) of Land and Resources (LRD) and the Department (Commission) of Housing and Urban-Rural Construction (HURC) are responsible for land purchase and reservation and for reviewing construction project licenses for redevelopment. The Finance Department (Bureau) (FD) is responsible for developing investment and financing policies for soil environmental protection, and for achieving central funds and taking it into a comprehensive budget of related departments. The Department (Commission) of Science and Technology (STD) is responsible for the research, development, demonstration, and guidance of soil remediation technology.

Polluters, developers and companies are most affected by either national or provincial policies for contaminated site management. Polluters and developers entrust qualified companies to investigate polluted soil, assess environment risks, remediate contaminated sites and undertake all costs while local government will take responsibilities mentioned above where there is unclear ownership or responsibility. As a result of regulation, the firms engaged in investigation, assessment, remediation and validation should keep documents in municipal environmental protection department, and avoid secondary soil pollution and any other potential danger when carrying out soil remediation projects.

The public have the obligation to protect the environment and are prohibited from discarding various wastes to pollute the soil. In 


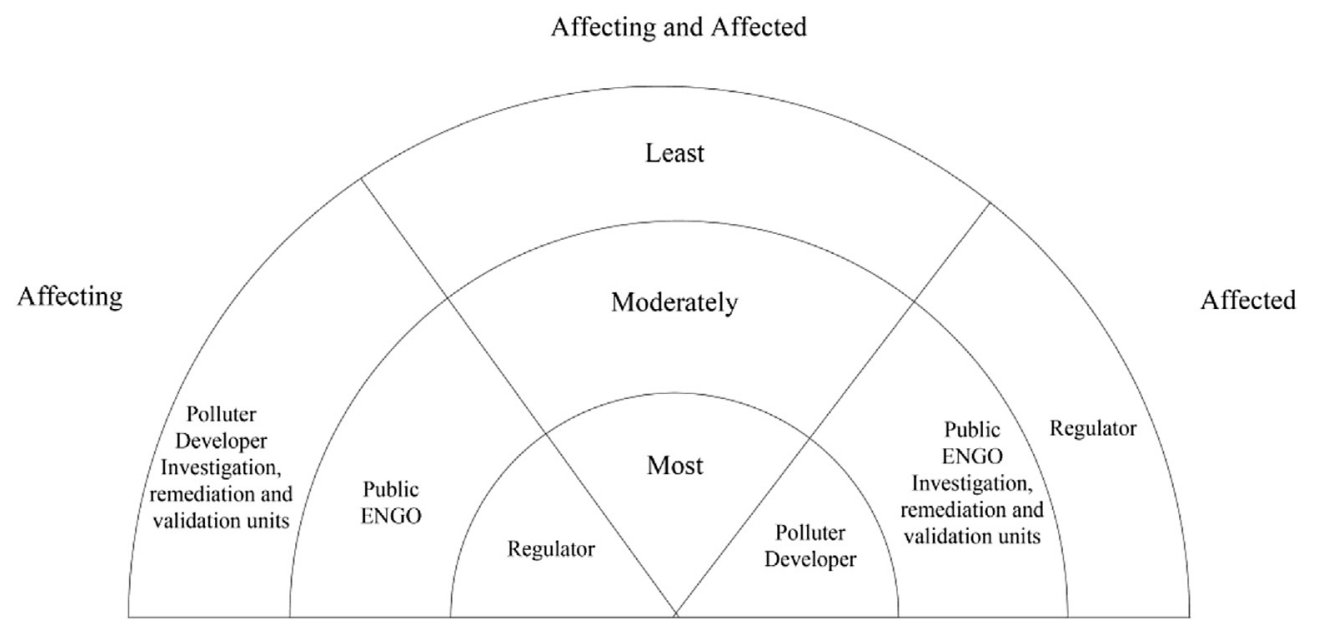

Fig. 2. Rainbow diagram for classifying stakeholders.

addition, the public who suffer from soil pollution, especially those living near contaminated sites, have the right to report and accuse the violators who caused the site polluted in question. They also have the right to attend hearings to give their opinion about contaminated sites which they feel significantly affect the environment and jeopardize public interest. They also have the right to comment on their social needs and interests, which will influence social decision making and avoid poor policy formulation and decision making. Environment Non-Government Organizations (e.g. Friends of Nature) are an important social force in the field of environmental protection, and can significantly promote contaminated site management in China by various methods such as disseminating hazards, prevention, control and treatment of contaminated sites through materials distribution, training, seminars and media to increase public awareness for the need of soil protection, striving on behalf of victims (blood lead) from the government and various enterprises, raising funds from environmentalists and the Environmental Protection Foundation to remediate polluted sites.

In China, there are not yet detailed guidelines for stakeholder identification such as region 7 in the U.S. Table 2 lists stakeholders identified in different provinces and their responsibility under current policies.

\section{Policy instruments in various regions}

Table 3 summarized policy instruments defined in 31 regions. Among the 17 instruments, the access mechanism, secondary pollution prevention, remediation standards, information disclosure, public participation and outreach and education are less presented (less than 7 of the 31 regions). For the access mechanism, Declaration Guides for Directory of Contaminated Sites Assessment, Consulting and Remediation (2013) by Chongqing Environmental Protection Bureau is China's first guide for industrial qualification to standardize declaration conditions, declaration procedures and management regulations. Shaanxi strictly examined and verified qualification management of companies engaged in environmental investigation, risks assessment and remediation of contaminated sites following access conditions made by the Ministry of Environmental Protection (MEP). For secondary pollution, Shaanxi, Zhejiang, Hubei and Liaoning pointed that remediation projects should obey regional policies to prevent secondary pollution, and for security protection, but lacked specified measures to implement. Policy instruments of remediation standards, outreach and education, information disclosure and public participation have been stated in the previous section.

Twenty-eight regions in Table 3 stipulated that the environmental situation of contaminated sites must be investigated and assessed to prepare a soil remediation plan before redevelopment The supervision mechanism (24), information management (21) and priority remediation (17) are significantly emphasized in provincial policies as follows: the whole process supervision mechanism by multi-sectors as "the people's governments at various levels bear the overall responsibility, departments of environmental protection are in charge of uniform management while departments of finance and others function as coordination"; multi-approaches of information management as "file, database, list and classification"; areas of priority remediation as "high pollution concentration and high risks, sewage irrigated farmland, heavily polluted industries, drinking water and groundwater sources, farmland and sites polluted by heavy metal, hazardous wastes and persistent organic compounds". Identifying the person responsible for polluted sites is of particular importance so that work on contaminated site management is promoted, while different regions have different opinions on the people who are responsible and the responsibilities they should take, even different policies in the same area (Shaanxi and Zhejiang) have disagreements on responsibilities (Table 4). The details of other policy instruments in each region are shown in Table 4.

\section{Policy types in various regions}

According to the situation in China, policies for the management of contaminated sites can be divided into six types, namely, environmental protection planning (EPP), prevention and control planning for heavy metal pollution (PHMP), notice on site management regarding industrial relocation (NMIR), regulation of contaminated sites remediation (RCSR), regulations on prevention and treatment of environmental pollution caused by solid waste (RPSW) and others. Fig. 3 illustrates the number of regions for different policy types.

Twenty-seven regions implemented environmental management of contaminated sites by EPP, which is the most applied among the six policy types. Except Jilin, Anhui, Hainan, Tibet and Shaanxi, all other regions in China have established special chapters on measures of soil protection and soil pollution prevention without detailed requirements on remediation standards, access mechanism, validation mechanism, financing mechanism, 
Table 2

Stakeholder definition in 31 regions.

\begin{tabular}{|c|c|c|}
\hline Stakeholder & Content & Province \\
\hline \multirow[t]{4}{*}{ Polluter } & Remediate contaminated soil & Beijing, Shaanxi, Sichuan \\
\hline & Investigate site environment, assess risks, remediate soil and bear expense & $\begin{array}{l}\text { Hubei, Zhejiang, Chongqing, Liaoning, } \\
\text { Jiangsu, Jilin }\end{array}$ \\
\hline & Investigate site environment, assess risks and remediate polluted soil & $\begin{array}{l}\text { Inner Mongolia, Shaanxi, Gansu, Beijing, } \\
\text { Sichuan, Fujian, Shandong, Guangdong }\end{array}$ \\
\hline & Issue notice of contaminated site remediation upon completion & Hubei \\
\hline $\begin{array}{l}\text { Multi-sectors } \\
\text { supervision }\end{array}$ & $\begin{array}{l}\text { The people's governments at various levels bear the overall responsibility, the departments of } \\
\text { environmental protection are in charge of uniform management while other departments function as } \\
\text { coordinators. }\end{array}$ & $\begin{array}{l}\text { Hunan, Henan, Shaanxi, Sichuan, } \\
\text { Chongqing, Jiangsu, Zhejiang, Liaoning, Jilin, } \\
\text { Gansu }\end{array}$ \\
\hline \multirow[t]{10}{*}{ EPD } & Examine feasible plans for contaminated site investigation and remediation & Beijing, Jiangsu, Liaoning \\
\hline & Develop specific soil policies & Beijing, Jiangsu, Sichuan \\
\hline & Unified supervision and management & $\begin{array}{l}\text { Fujian, Hubei, Chongqing, Jiangsu, Zhejiang, } \\
\text { Inner Mongolia, Liaoning }\end{array}$ \\
\hline & Organize site investigation in industrial areas & Gansu, Jiangsu, Shaanxi \\
\hline & Clarify accountability of violators & $\begin{array}{l}\text { Hunan, Henan, Shaanxi, Sichuan, } \\
\text { Chongqing, Jiangsu, Zhejiang, Inner } \\
\text { Mongolia, Liaoning }\end{array}$ \\
\hline & Organize validation for contaminated soil remediation & $\begin{array}{l}\text { Jiangsu, Zhejiang, Henan, Hunan, Gansu, } \\
\text { Shaanxi }\end{array}$ \\
\hline & Guide, train and promote technology and experience & Hubei, Shaanxi, Chongqing, Jiangsu \\
\hline & Establish contaminated site lists & $\begin{array}{l}\text { Jiangsu, Zhejiang, Inner Mongolia, Liaoning, } \\
\text { Shaanxi }\end{array}$ \\
\hline & Facilitate soil remediation fund & Jiangsu \\
\hline & $\begin{array}{l}\text { Public information of contaminated site investigation, risk assessment, remediation and validation, and } \\
\text { provide approaches for public participation }\end{array}$ & Jiangsu, Liaoning \\
\hline \multirow{2}{*}{$\begin{array}{l}\text { The people's } \\
\text { governments }\end{array}$} & Organize site investigation in industrial areas & Beijing, Zhejiang \\
\hline & $\begin{array}{l}\text { Bear the overall responsibility for soil environmental protection and comprehensive management of the } \\
\text { administrative areas }\end{array}$ & Jiangsu, Zhejiang, Gansu \\
\hline DRC & $\begin{array}{l}\text { Develop industrial policies for eliminating backward production capacity and upgrading the industrial } \\
\text { structure to prevent soil pollution }\end{array}$ & Jiangsu, Sichuan \\
\hline STD & Promote the research and demonstration of remediation technology & Jiangsu \\
\hline HURC & Supervise redevelopment of potentially contaminated land & Jiangsu, Sichuan, Zhejiang \\
\hline \multirow[t]{2}{*}{ FD } & Collect and implement soil remediation fund & Beijing, Sichuan, Zhejiang \\
\hline & Develop taxation and investment policies to protect soil environment & Jiangsu \\
\hline EITC & Be responsible for industrial restructuring and layout & Beijing, Sichuan, Zhejiang \\
\hline LRD & Be responsible for land purchase and reservation, and the construction project license for redevelopment & Jiangsu, Sichuan, Zhejiang, Gansu \\
\hline Detection units & Validate effectiveness of soil remediation according to relative regulations & Hubei, Jiangsu \\
\hline $\begin{array}{l}\text { Remediation } \\
\text { units }\end{array}$ & $\begin{array}{l}\text { Develop soil remediation program, avoid secondary soil pollution and hidden dangers when carrying out } \\
\text { the soil remediation projects }\end{array}$ & Hubei, Jiangsu, Shaanxi \\
\hline \multirow[t]{2}{*}{ Public } & Apply for information disclosure & Jiangsu \\
\hline & Report and accuse violators who cause site pollution & Liaoning \\
\hline Redeveloper & Entrust qualified units to assess environmental impacts & Shaanxi, Zhejiang, Jiangsu \\
\hline
\end{tabular}

preventing secondary pollution and public participation.

Nine regions including Fujian, Hubei, Hunan, Liaoning and Shandong established the PHMP. Their PHMP mainly focus on source prevention, process control and final treatment of heavy metal through industrial life cycle, while terms of information management, liability and priority remediation list are simply referred to promote remediation pilot projects and resolve historical issues.

As a consequence of the following statement: "government at all levels and related departments should attach great importance to risk assessment and remediation of contaminated sites" given in Notice on Ensuring Safe Environment of Redevelopment and Reutilization of Industrial Sites (2012), eight areas including Beijing, Chongqing, Shaanxi and Zhejiang have issued local NMIR to protect human health and environmental safety but without practicable definition on remediation standards, financing mechanism, public participation, outreach and education. The NMIR of Beijing and Jiangsu focus on liability, EIA, supervision mechanism and contaminated site list while other areas are involved in all aspects (Table 5).

Until now, China has issued many policies to prevent and control soil pollution at national and provincial levels in which specialized standards, norms and guidelines undoubtedly are the most effective types for their maneuverability, pertinence, authority, standardization and systematization. Beijing, Chongqing, Jiangsu, Liaoning, Zhejiang and Sichuan have taken positive action on developing specialized policies, involving polices of Technical Guideline for Contaminated Sites Remediation Validation (2011) and Administrative Methods for Cleanup and Remediation of Contaminated Lands in Shenyang (2007, trial edition). Chongqing and Zhejiang formulate guidelines for risk assessment of contaminated sites to define the principles, contents, procedures, methods and technical requirements for human health risk assessment. Jiangsu and Sichuan developed Plan of Soil Environment Protection and Comprehensive Cleanup (2013) to propose the recent goals, tasks, key projects and measures for environmental protection of soils based on province-specific situation. Shanghai, Guizhou and Ningxia Autonomous Regions are preparing the Plan now.

Targeting sites that have been polluted by solid waste, Jiangsu, Zhejiang, Henan, Hunan, Shaanxi and Sichuan have issued RPSW presenting different ideas on liability, validation and EIA, but all agreed on clear penalty standards which is the most obvious feature in comparison to other policy types such as "severely punishing violations and violators that fail to remediate contaminated soil or redevelop remediated land that does not meet the requirements of environmental protection".

In addition to the five policy types mentioned above, Zhejiang, Gansu, Beijing, Jilin and Jiangxi have also issued other policies to 
Table 3

Policy instruments in 31 regions of China.

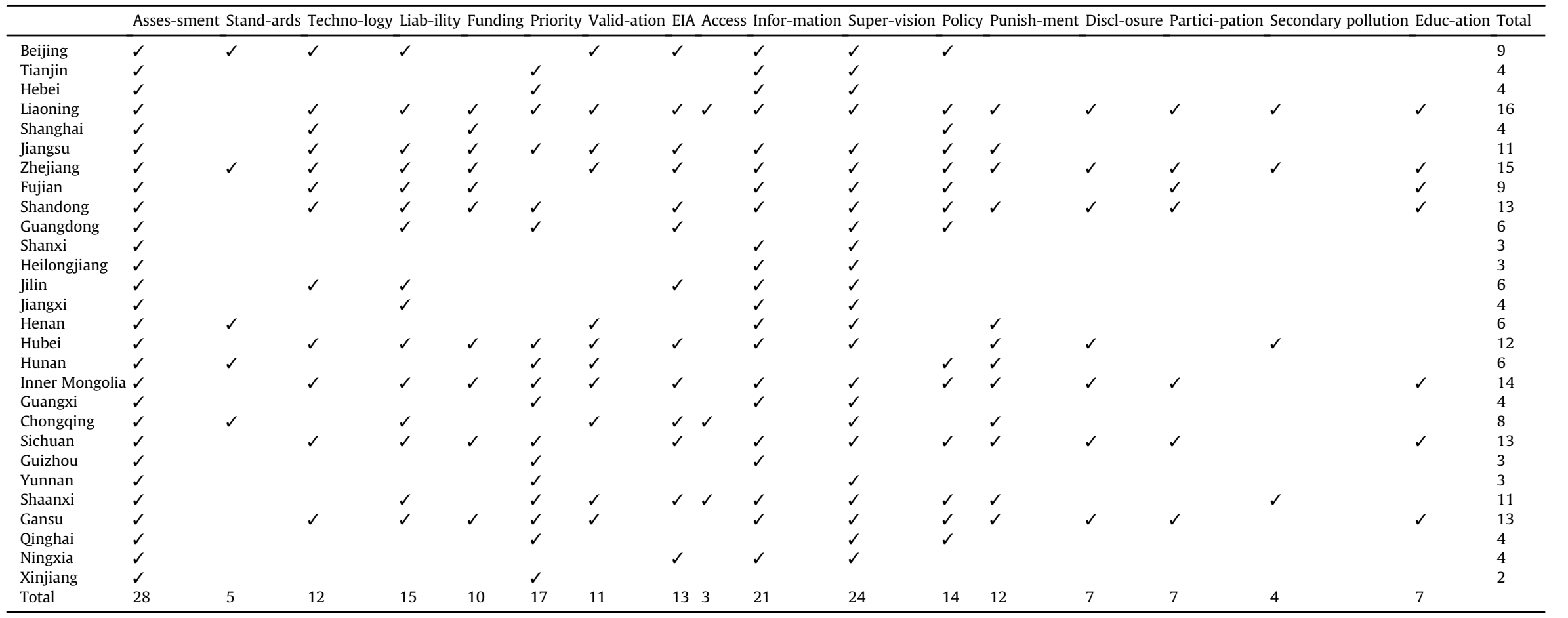


Table 4

Policy instruments applied in 31 regions.

\begin{tabular}{|c|c|c|}
\hline Policy instruments & Contents & Regions \\
\hline \multirow[t]{5}{*}{$\begin{array}{l}\text { Technical } \\
\text { mechanism }\end{array}$} & $\begin{array}{l}\text { Environmental protection departments facilitates guidance, training and promotes } \\
\text { advanced technologies. }\end{array}$ & Hubei, Shaanxi, Chongqing \\
\hline & Technical Guideline on Construction and Operation of Heavy Contaminated Soil Landfill & Beijing \\
\hline & Promote soil contamination risk assessment, research and development of remediation & Jiangsu, Zhejiang, Sichuan, Beijing, Shanghai, Liaoning, \\
\hline & technology and equipment. & Shandong, Hubei, Gansu, Inner Mongolia, Jilin \\
\hline & Develop professional institutions, professionals, technology centers and companies. & Zhejiang, Jiangsu \\
\hline \multirow[t]{4}{*}{ Liability mechanism } & $\begin{array}{l}\text { Polluters are responsible for the environmental investigation, risk assessment and } \\
\text { remediation. }\end{array}$ & $\begin{array}{l}\text { Inner Mongolia, Shaanxi, Gansu, Beijing, Sichuan, Fujian, } \\
\text { Shandong, Guangdong }\end{array}$ \\
\hline & $\begin{array}{l}\text { Polluters are responsible for the environmental investigation, risk assessment, } \\
\text { remediation and bear the expenses. }\end{array}$ & Hubei, Zhejiang, Chongqing, Liaoning, Jiangsu, Jilin \\
\hline & $\begin{array}{l}\text { Developers entrust qualified units to assess environmental impacts, polluters take } \\
\text { responsibility of remediation. }\end{array}$ & Shaanxi, Zhejiang, Jiangsu \\
\hline & Polluter takes responsibility, investor benefits. & Jiangxi \\
\hline \multirow{5}{*}{$\begin{array}{l}\text { Validation } \\
\text { mechanism }\end{array}$} & Safety validation upon completion. & Jiangsu, Inner Mongolia \\
\hline & $\begin{array}{l}\text { Liable persons entrust municipal or provincial statutory environmental monitoring } \\
\text { agency or qualified third-party assessment institution to validate remediation projects. }\end{array}$ & Chongqing, Hubei, Shaanxi, Zhejiang, Liaoning \\
\hline & Validation by environmental protection departments. & Jiangsu, Zhejiang, Henan, Hunan, Gansu \\
\hline & Special validation according to remediation schemes. & Shaanxi \\
\hline & $\begin{array}{l}\text { Special validation according to EIA documents approved by environmental protection } \\
\text { departments. }\end{array}$ & Jiangsu \\
\hline $\begin{array}{l}\text { Environmental } \\
\text { impact } \\
\text { assessment (EIA) }\end{array}$ & $\begin{array}{l}\text { Consider risk assessment and remediation of contaminated sites into EIA before land } \\
\text { redevelopment. }\end{array}$ & $\begin{array}{l}\text { Beijing, Hubei, Chongqing, Inner Mongolia, Jiangsu, } \\
\text { Zhejiang, Sichuan, Guangdong, Ningxia, Shandong, } \\
\text { Shaanxi, Jilin }\end{array}$ \\
\hline \multirow[t]{2}{*}{ Policy system } & $\begin{array}{l}\text { Issue policies in three aspects, such as investigation, assessment and remediation to } \\
\text { regulate contaminated sites management. }\end{array}$ & $\begin{array}{l}\text { Shaanxi, Jiangsu, Zhejiang, Beijing, Inner Mongolia, } \\
\text { Guangdong, Qinghai, Liaoning, Gansu, Hubei, Fujian, } \\
\text { Sichuan, Shandong }\end{array}$ \\
\hline & Focus on technical guidelines & Shanghai, Guangdong, Zhejiang, Sichuan \\
\hline \multirow[t]{4}{*}{ Legal punishment } & Criticism & Chongqing, Hubei, Shaanxi \\
\hline & Accountability & Chongqing, Hubei, Shaanxi, Gansu, Jiangsu \\
\hline & Punishment & Chongqing, Inner Mongolia, Liaoning, Zhejiang \\
\hline & Deadline for correction & $\begin{array}{l}\text { Inner Mongolia, Liaoning, Henan, Hunan, Jiangsu, Shaanxi, } \\
\text { Sichuan, Zhejiang, Chongqing }\end{array}$ \\
\hline
\end{tabular}

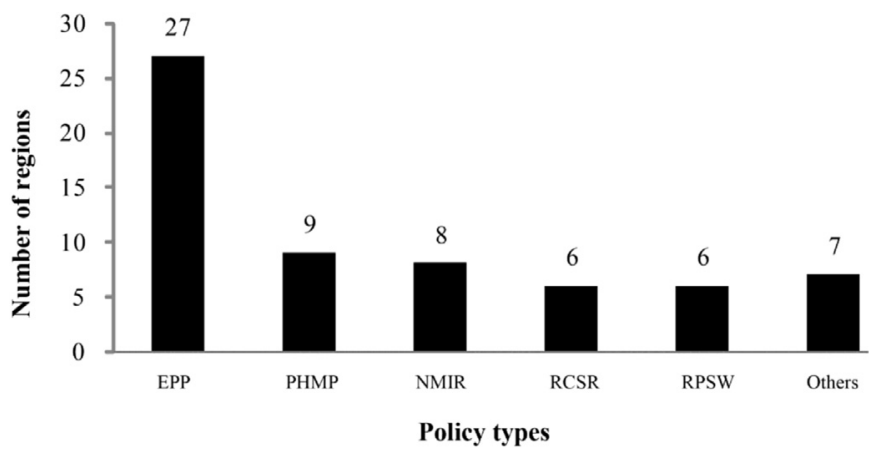

Fig. 3. Policy type distribution of 31 regions.

regulate the management of contaminated sites such as the Action Program of Zhejiang to Promote the Construction of "811" Ecological Civilization (2011) and Action Program of Beijing on Groundwater Protection and Pollution Prevention and Control (2013), in which responsibilities of related departments were clearly defined, providing valuable references for soil-directed legislation.

\section{Spatial and temporal variation of policies in different regions}

Fig. 4 shows the policy types (EPP, PHMP, NMIR, RCSR, RPSW and others) by issued time and regions. Anhui, Hainan and Tibet are the only three regions that do not issue contaminated site management policies.

In general, the more developed eastern regions like Zhejiang and Jiangsu issued more policies covering a greater range of policy types. Among these, Zhejiang issued the greatest number of policies with a total of ten, involving six types and including two specialized policies for soil pollution prevention and control, namely, Guidelines for Risk Assessment of Contaminated Site in Zhejiang (unreleased) and Action Program of Zhejiang on Cleaning Soil (2011). Six policies were issued in Beijing and Jiangsu, among which Beijing has established a local regulatory framework for contaminated site management, Jiangsu is the first to respond to the State Council to develop Recent Plan of Soil Environment Protection and Comprehensive Cleanup (2013). Meanwhile, the local cities in Jiangsu such as Nanjing and Yancheng have also issued policies to safely dispose polluted soil caused by solid wastes and industrial relocation.

The policy type to deal with contaminated sites in central and western regions is mainly EPP. As the key provinces defined in the 12th Five-Year Planning for Heavy Metal Contamination Prevention and Control (2011), Hubei and Hunan are the most positive and effective in regulating environmental management of contaminated sites by policy making. Chongqing leads policy making and practical remediation in western region as well as in national level. A series of contaminated site management policies such as Notification on Implementing Soil Contamination Control and Treatment after Factory Relocation (2005), Notification on Strengthening the Remediation of Contaminated Former Industrial Sites (2008) and Declaration Guides for Directory of Contaminated Sites Assessment, Consulting and Remediation (2013) have been issued to conduct site remediation gradually since 2005 . As a result, the remediation and redevelopment of contaminated sites in Chongqing has made substantial progress, and 800 million RMB were invested on 45 sites and 5 pilot projects have been launched by 2009 (Xie and Li, 2010). Sichuan, Gansu, Inner Mongolia and Shaanxi of western region started their own research and prepared local regulations after 2011 while Guangxi, Guizhou, Ningxia, Qinghai, Xinjiang and Yunnan lag far behind other provinces in contaminated site management to the extent that they only implement remediation and 
Table 5

Details of policy instruments in NMIR in different regions.

\begin{tabular}{|c|c|c|}
\hline Policy instruments & Contents & Regions \\
\hline $\begin{array}{l}\text { Technical } \\
\text { mechanism }\end{array}$ & Environmental protection departments facilitates guidance, training and promotes advanced technologies. & Hubei, Shaanxi, Chongqing \\
\hline \multirow[t]{2}{*}{$\begin{array}{l}\text { Liability } \\
\text { mechanism }\end{array}$} & Polluters are responsible for the environmental investigation, risk assessment, remediation. & $\begin{array}{l}\text { Inner Mongolia, Jiangsu, Shaanxi, } \\
\text { Chongqing, Gansu, Beijing }\end{array}$ \\
\hline & $\begin{array}{l}\text { Polluters are responsible for the environmental investigation, risk assessment, remediation and bear the } \\
\text { expenses. }\end{array}$ & Hubei, Zhejiang, Chongqing \\
\hline \multirow{2}{*}{$\begin{array}{l}\text { Priority } \\
\quad \text { remediation }\end{array}$} & Give priority of risk assessment and remediation to sites of high risk. & Zhejiang \\
\hline & Give priority of remediation to sites of high polluted which affect living environment and drinking water. & Shaanxi \\
\hline $\begin{array}{l}\text { Preventing } \\
\text { secondary } \\
\text { pollution }\end{array}$ & Obey regional policies to prevent secondary pollution and security protection in remediating polluted soil. & Shaanxi, Zhejiang, Hubei \\
\hline \multirow{2}{*}{$\begin{array}{l}\text { Validation } \\
\text { mechanism }\end{array}$} & Safety validation upon completion. & Jiangsu, Inner Mongolia \\
\hline & $\begin{array}{l}\text { Liable person entrust municipal or provincial statutory environmental monitoring agency or qualified third- } \\
\text { party assessment institution to validate remediation projects. }\end{array}$ & Chongqing, Hubei, Shaanxi, Zhejiang \\
\hline EIA & Consider risk assessment and remediation of contaminated sites into EIA before land redevelopment. & $\begin{array}{l}\text { Beijing, Hubei, Chongqing, Zhejiang, } \\
\text { Jiangsu, Inner Mongolia }\end{array}$ \\
\hline Access mechanism & $\begin{array}{l}\text { Examine and verify qualification of companies engaged in environmental investigation, risks assessment and } \\
\text { remediation of contaminated sites following access conditions made by MEP. }\end{array}$ & Shaanxi \\
\hline \multirow{4}{*}{$\begin{array}{l}\text { Information } \\
\text { management }\end{array}$} & Information sharing mechanism & Zhejiang, Inner Mongolia \\
\hline & List & Zhejiang, Jiangsu \\
\hline & Database & Inner Mongolia, Jiangsu \\
\hline & File & Shaanxi, Inner Mongolia, Jiangsu \\
\hline $\begin{array}{l}\text { Supervision } \\
\text { mechanism }\end{array}$ & $\begin{array}{l}\text { The people's governments at various levels bear the overall responsibility, the departments of environmental } \\
\text { protection are in charge of uniform management while departments of land and resources, industry and } \\
\text { information and others function as coordination. }\end{array}$ & $\begin{array}{l}\text { Gansu, Zhejiang, Jiangsu, Chongqing, } \\
\text { Hubei, Shaanxi }\end{array}$ \\
\hline Policy system & $\begin{array}{l}\text { Issue policies in three aspects, such as investigation, assessment and remediation to regulate contaminated } \\
\text { sites management. }\end{array}$ & Shaanxi \\
\hline \multirow[t]{3}{*}{ Legal punishment } & Criticism and accountability & Gansu, Chongqing, Hubei, Shaanxi \\
\hline & Punishment & Chongqing, Inner Mongolia \\
\hline & Deadline for correction & Inner Mongolia \\
\hline $\begin{array}{l}\text { Information } \\
\text { disclosure }\end{array}$ & Announce notice of contaminated site remediation upon completion. & Hubei \\
\hline
\end{tabular}

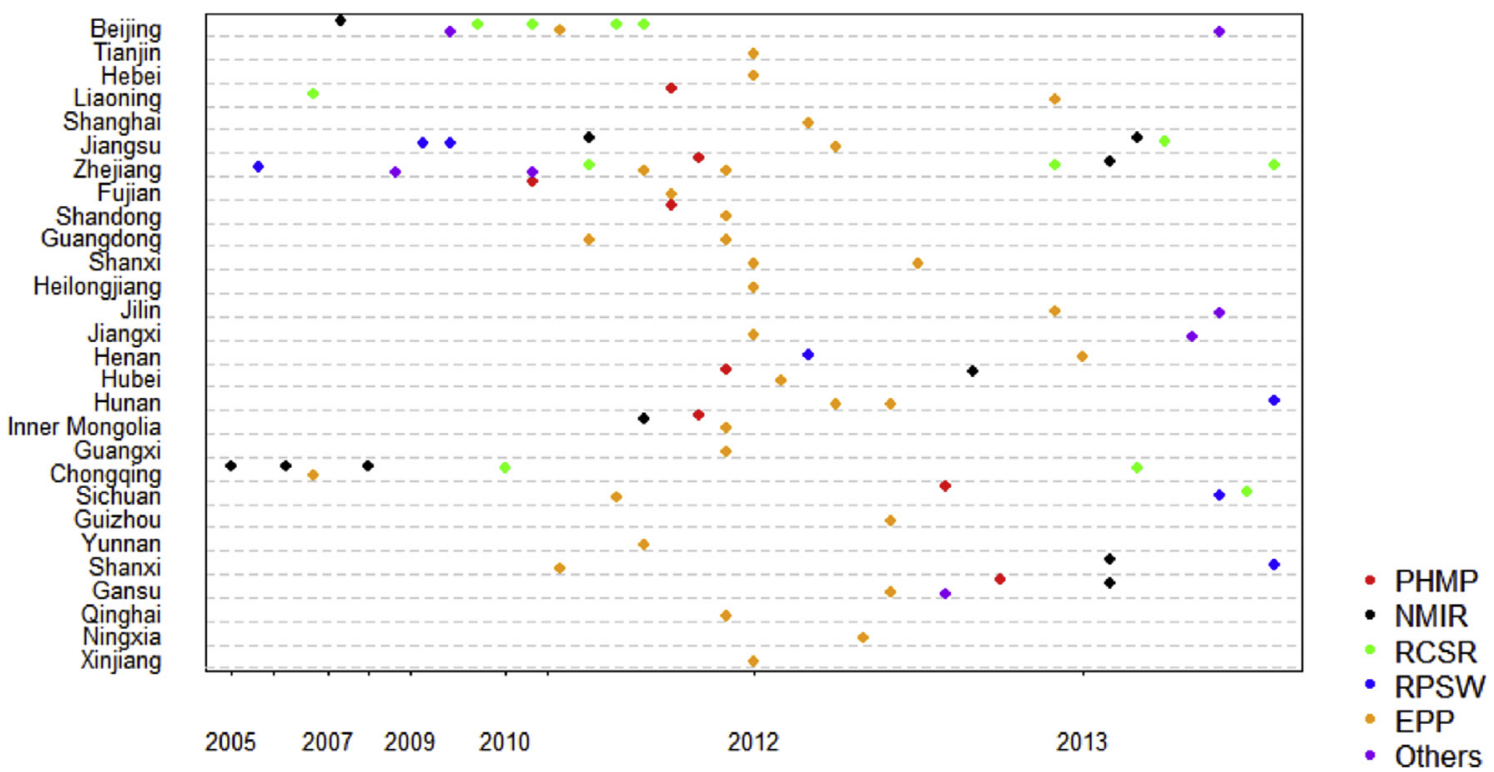

Fig. 4. Temporal and spatial distribution of contaminated site management policies

supervision of contaminated sites through EPP but lacking physical supports.

As shown in Fig. 4, the policy making development process for contaminated site management in China during the last ten years can be divided into two stages: the initial stage from 2005 to 2010 and the rapid developing stage since 2011.

During the initial stage, only a few regions such as Beijing, Chongqing, Liaoning, Zhejiang and Jiangsu started exploring the concept of contaminated site management. The poisoning incident of Songjiazhuang Subway Station in 2004 was a turning point in the sense that public and authorities were more aware of contaminated site issues (Xie and Li, 2010). Following the incident, a series of local regulations were issued by various governmental bodies. Chongqing was the first to issue policies in 2005, 2006 and 2008 with the goal of preventing soil pollution of land redevelopment after industrial relocations, strengthening the management of solid waste left from shut-down, bankrupt and relocated factories and promoting the remediation of contaminated industrial sites. Zhejiang, 
Beijing, Liaoning and Jiangsu made mandatory provisions on environmental management of risk assessment, remediation and redevelopment of sites polluted by industrial relocations, solid wastes and PCBs.

The rapid developing stage is characterized by policy making combing local specific situations and response to fundamental requirements of national policies. About 80 percent of the policies were issued in this period because of rich theoretical and practical experiences accumulated from pervious researches. Twenty-seven regions issued EPP to prevent soil pollution and protect soil environment during 2011-2013. Eight provinces including Fujian, Liaoning and Zhejiang issued PHMP considering local status of heavy metal pollution to designate key areas, industries and historical contaminated sites for pollution prevention, control and remediation. Five provinces including Jiangsu, Zhejiang and Shaanxi issued NMIR to make detailed provisions on soil pollution left by shut-down, bankrupt and relocated factories.

\section{Discussion and conclusions}

Most regions in China have taken positive measures to manage contaminated sites but the actions, responses, policies and mechanisms are quite different between provinces. Moreover, the factors considered into the guidelines, values (and the methods for deriving such values), responsibilities, the ways and extent of legal punishment to violators and the procedures for identifying priority regions to be remediated are also very different. In spite of the large divergences, there are certain viewpoints that all 31 regions agree on:

- The multi-level objective framework to achieve the long-term ultimate objective through controllable phased objectives and practical action objectives.

- Combination of command and control instruments, economic stimulation instruments, and persuasion and encouragement instruments to realize the objectives.

- Cooperation between different stakeholders including governmental departments, polluters, developers, consulting and remediation companies, the public and NGOs.

- Investigation, risk assessment and remediation of contaminated sites before land redevelopment, and multi-sectoral joint supervision mechanism throughout the whole processes.

- The need to develop specific policies and improve access mechanism, secondary pollution prevention, standards, information disclosure, public participation, outreach and education.

An effective policy system must be developed not only at national, regional and local but also international. To promote the sustainable management of contaminated sites for possible land redevelopment, six recommendations based on our analysis and referred to international successful experiences, are given bellow:

(1) Generic policies may be used as instructive guidelines, while specialized standards, norms for environmental investigation, risk assessment, remediation and validation of contaminated sites should be issued in each region with consideration of regional differences. Beijing, Chongqing, Jiangsu, Liaoning, Zhejiang and Sichuan are good examples of these.

(2) Contaminated sites have to be managed before, during and after remediation, and the cooperation between stakeholders (regulators, polluters, the public) influences the effectiveness and the way contaminated sites are managed. Therefore, stakeholders' coordination such as implementing regulation of government departments, promoting polluters to prevent, control pollution and remediate soil, and encouraging public participation are identified as extremely vital for the sustainable management of contaminated sites. In particular, residents located near contaminated sites, their communication with policy stakeholders could be significantly important in helping designing and implementing meaningful policies that address community priorities, avoiding conflicts and enhancing credibility to support remediation plans.

(3) Policy making has to consider site regionality according to the specific context of regions where the policies will be implemented. The social, economic and environmental context of different regions could significantly vary, which means the effective management measures taken by some cities cannot be expected the same results everywhere. For instance, decisions about the range and standards of risk assessment and remedial actions should be defined depending on land use types (present and future), potential receptors and exposure pathways. For regions using groundwater for water supply especially for drinking water (e.g. Beijing and Hebei), the soil screening values and remediation goals can be derived based on drinking water quality standards along with other general criteria including social acceptability, economic and technical feasibility, and environmental sustainability.

(4) Information disclosure, outreach and education and public participation must be implemented together to improve the diversity of persuasion and encouragement which are less mentioned and poorly implemented of all instruments. Information openness as well as transparency of access to information must be considered the premise of effective public participation. On one hand, information on site distribution, soil quality and contaminated sites remediation, which serves as a database for policy decisions, should also be transferred to developers and the public by media (website, newspaper, television), material distribution, science popularization, press conferences, information bulletin board and communication platform (WeChat, micro-blog). On the other hand, multi-approaches of email, telephone, letter, interview, seminar and hearing should be developed to encourage public involvement early in project implementation.

(5) Policy on remediation priority should be developed at the regional level considering the large number, rich varieties, wide and scattered distribution of contaminated sites in China and the limited availability of funds for remediation. Contamination at residential sites and groundwater protection should be given the top priority to reduce human health risks directly and indirectly. The remediation should be paid by polluters whenever liable parties are identified, while, in other cases, local governments take responsibility of site remediation using a variety of funding sources and financial incentives (the central special fund, tax abatement/credits, grants for remediation and loan) which can learn from Superfund.

(6) Regulations on groundwater protection should be embodied as an important issue in future policy development and decision making, which is not well represented in current policy contents. Surface waters or groundwater is legally defined in the UK as one of substances that can be caused significant pollution by contaminated land, in particular, shallow groundwater is susceptible to be influenced by surface contamination. The possibility of groundwater pollution depends not only on the geological and hydrological setting but also physical, chemical and biological properties of pollutants. An initial hydrogeological assessment 
supplementing site investigation is therefore helpful to identify if there is potential risk for groundwater, how contaminants and ground water interrelates, and eventually address pollution prevention or remediation.

In general, some provinces have been trying to actively respond to the urgent need for contaminated site management. For example, Jiangsu has started investigation of contaminated sites to establish files for sites after industry relocation; Henan decides to start soil environment protection projects and conduct soil remediation pilot soon. It is clear that there exists and will continue to be diverse in policy decisions among different regions. Overall, an effective contaminated site management strategy is able to support polluted site remediation and land redevelopment with full consideration of the key factors, which are identified by our research, including specific regulations, stakeholder participation, assessment and remediation standards, persuasion and encouragement instruments, the polluter pays principle, priority remediation lists and multi-source financing.

\section{Conflicts of interest}

The authors declare that there is no conflict of interests regarding the publication of this paper.

\section{Acknowledgements}

Special appreciation for proofreading to my colleagues Ruth Preston and Johan David Coronado Jimenez in University of Brighton.

This work was supported by National Natural Science Foundation of China (\#41173123, \#41201601).

\section{References}

Banisar, David, 2006. Freedom of Information Around the World. Privacy International, London.

Bardos, P., Menger, P., 2013. Conceptual Site or Project Models for Sustainability Assessment. ThS D3.3 Methods and Tools for Environmental Footprint Assessment. Available at: http://www.r3environmental.co.uk/downloadsnew/Aqua consoil_2013_2284_Conceptual_Site_or_Project_Models_for_Sustainability Assessment_v3.pdf (Accessed 07 July 2016).

Bergius, K., Öberg, T., 2007. Initial screening of contaminated land: a comparison of US and Swedish methods. J. Environ. Manage 39 (2), 226-234. http:// dx.doi.org/10.1007/s00267-006-0005-4.

Beumer, V., Bardos, P., Menger, P., 2014. HOMBRE D 5.2: Decision Support System on Soft Reuses. HOMBRE Deliverable D 5-2. Deltares. Available at: http://www. zerobrownfields.eu/HombreTrainingGallery/HOMBRE_D5.2_final.pdf (Accessed 07 July 2016).

Bluffstone, R., 2007. Privatization and contaminated site remediation in central and eastern Europe: do environmental liability policies matter? Ecol. Econ. 63 (1), 31-41. http://dx.doi.org/10.1016/j.ecolecon.2006.08.006.

Bouma, J., Droogers, P., 2007. Translating soil science into environmental policy: a case study on implementing the EU soil protection strategy in The Netherlands. Environ. Sci. Policy 10 (5), 454-463. http://dx.doi.org/10.1016/ j.envsci.2007.02.004.

Chang, D.H., Ma, Z., Wang, X., 2013. Framework of wastewater reclamation and reuse policies (WRRPs) in China: comparative analysis across levels and areas. Environ. Sci. Policy 33, 41-52. http://dx.doi.org/10.1016/j.envsci.2013.05.006.

Chevalier, J.M., Buckles, D.J., 2008. A Guide to Collaborative Inquiry and Social Engagement. Available at: http://omec.uab.cat/Documentos/coop_ internacional/00110.pdf (Accessed 25 August 2016).

Contaminated Land: Applications in Real Environments (CL:AIRE), 2011. The SuRFUK Indicator Set for Sustainable Remediation Assessment. ISBN: 978-1-9050461292-5. Available at: http://www.claire.co.uk/index.php?option=com_ content\&view=article\&id=748:annex-1-surf-uk-indicator-set-for-sustainableremediation\&catid $=966 \&$ Itemid $=78$ (Accessed 07 July 2016).

Cundy, A.B., Bardos, R.P., Church, A., Puschenreiter, M., Friesl-Hanl, W., Müller, I., Neu, S., Mench, M., Witters, N., Vangronsveld, J., 2013. Developing principles of sustainability and stakeholder engagement for "gentle" remediation approaches: the European context. J. Environ. Manage 129 (15), 283-291. http:// dx.doi.org/10.1016/j.jenvman.2013.07.032.
D'Aprile, L., Tatàno, F., Musmeci, L., 2007. Development of quality objectives for contaminated sites: state of the art and new perspectives. Int. J. Environ. Health 1 (1), 120-141.

Department for Environment Food \& Rural Affairs (Defra), 2012. Environmenta Protection Act 1990: Part 2A. Available at: http://www.legislation.gov.uk/ukpga/ 1990/43/part/IIA (Accessed 08 November 2016).

Everbright Securities, 2013. Soil Remediation: 700 Billion "feast" under Policy Approaching. Available at: http://pg.jrj.com.cn/acc/Res/CN_RES/INDUS/2013/9 3/eb13500d-027d-48e6-854d-667e5f262baf.pdf (Accessed 25 August 2016).

Gong, Y.Y., 2012. Contaminated Site Management and Remediation. China Envionmental Science Press, China, Beijing.

Greenberg, M., Lewis, M.J., 2000. Brownfields redevelopment, preferences and public involvement: a case study of an ethnically mixed neighborhood. Urban Stud. 37 (13), 2501-2514. http://dx.doi.org/10.1080/00420980020080661.

Gu, Q.B., Yan, Z.G., Zhou, Y.Y., Guo, G.L., Li, F.S., 2007. Critical review of Superfund Act and environmental management of Superfund sites. Res. Environ. Sci. 20 (5), $84-88$

Jin, L., 2012. Legislation Research on Prevention and Control of China Soil Pollution. Jilin University, China, Jilin.

Johansson, M.V., Forslund, J., Johansson, P., Samakovlis, E., 2011. Can we buy time? Evaluation of the Swedish government's grant to remediation of contaminated sites. Environ. Manage 92 (4), 1303-1313. http://dx.doi.org/10.1016 j.jenvman.2010.12.017.

Li, F., 2011. Study on Soil Environmental Management and Remediation Measure of Contaminated Sites. China University of Geosciences, China, Beijing.

Li, X., 2012. Research on Legal System of Soil Contamination Prevention and Control. Shanxi University of Finance and Economics, China, Shanxi.

Liao, X.Y., Chong, Z.Y., Yan, X.L., Zhao, D., 2011. Urban industrial contaminated sites: a new issue in the field of environmental remediation in China. Environ. Sci. 32 (3), 784-793.

Liu, Y.M., Li, Y.C., Xiao, R.B., 2013. Management experience of industrial contaminated sites in western countries and its implications for China. Ecol. Environ. Sci. 22 (8), 1438-1443.

Luo, Q.S., Catney, P., Lerner, D., 2009. Risk-based management of contaminated land in the UK: lessons for China? J. Environ. Manage 90 (2), 1123-1134. http:// dx.doi.org/10.1016/j.jenvman.2008.05.001.

Ma, J.R., 2009. Identification, Diagnosis and Composting Remediation of a Complex Contaminated Site, Nanjing Agricultural University, China, Nanjing.

Prokop, G., 2005. The state of EU soil policy and soil related research. Rev. Environ. Sci. Bio/Technol. 4 (3), 81-86. http://dx.doi.org/10.1007/s11157-005-2239-7.

Provoost, J., Cornelis, C., Swartjes, F., 2006. Comparison of soil clean-up standards for trace elements between countries: why do they differ? J. Soils Sediments 6 (3), 173-181. http://dx.doi.org/10.1065/jss2006.07.169.

Rodrigues, S.M., Pereira, M.E., da Silva, E.F., Hursthouse, A.S., Duarte, A.C., 2009 A review of regulatory decisions for environmental protection: part I-challenges in the implementation of national soil policies. Environ. Int. 35 (1), 202-213. http://dx.doi.org/10.1016/j.envint.2008.08.007.

Song, G.J., 2008. China's Environmental Policy Analysis. Chemical Industry Press, China, Beijing.

Sousa, C.D., 2001. Contaminated sites: the Canadian situation in an international context. J. Environ. Manage 62 (2), 131-154. http://dx.doi.org/10.1006/ jema.2001.0431.

Swartjes, F.A., Rutgers, M., Lijzen, J.P.A., Janssen, P.J.C.M., Otte, P.F., Wintersen, A., Brand, E., Posthuma, L., 2012. State of the art of contaminated site management in The Netherlands: policy framework and risk assessment tools. Sci. Total Environ. 427-428, 1-10. http://dx.doi.org/10.1016/j.scitotenv.2012.02.078.

Tarazona, J.V., Fernandez, M.D., Vega, M.M., 2005. Regulation of contaminated soils in Spain: a new legal instrument. J. Soils Sediments 5 (2), 121-124. http:/ dx.doi.org/10.1065/jss2005.05.135.

USEPA, 1980. Comprehensive Environmental Response, Compensation, and Liability Act (CERCLA). Available at: http://www.epa.gov/oecaagct/lcla.html (Accessed 25 August 2016).

United States Environmental Protection Agency (USEPA), 2016. NPL Site Totals by Status and Milestone. Available at: http://www.epa.gov/superfund/sites/query/ queryhtm/npltotal.htm (Accessed on 31 August 2016).

van Straalen, N.M., 2002. Assessment of soil contamination - a functional perspective. Biodegrad 13 (1), 41-52. http://dx.doi.org/10.1023/A: 1016398018140.

Wang, Y., 2012. Legal Research on the Establishment of Remediation System of Contaminated Site in PRC. East China University of Political Science and Law, China, Shanghai.

Xie, J., Li, F.S., 2010. Overview of the Current Situation Brownfield Remediation an Redevelopment in China. Available at: https://openknowledge.worldbank.org bitstream/handle/10986/2933/579530ESWOP1191se0situationOENOFull.pdf? sequence $=1$ (Accessed 25 August 2016)

Zhao, Q.N., Yang, K., Xu, Q.X. 2006. Comparative study on urban soil pollution control and management systems in China and USA. Soils 38 (1), 6-10. http:/ dx.doi.org/10.3321/j.issn:0253-9829.2006.01.002.

Zhu, J., 2011. Inspiration of soil pollution prevention legal system in United States and Japan to China. Environ. Sci. Manage 36 (11), 21-26. http://dx.doi.org 10.3969/j.issn.1673-1212.2011.11.005. 